\title{
Effect of Dao Jiang Ping (DJP) Model Based Module on Learning Result Students
}

\section{Suciati Suciati ${ }^{1 *}$, Maridi Maridi', Nurul Kusuma Dewi' ${ }^{2}$ Dedy Subandowo ${ }^{3}$, Anggit Sasmito ${ }^{1}$}

${ }^{1}$ Universitas Sebelas Maret, Indonesia

${ }^{2}$ Universitas PGRI Madiun, Indonesia

${ }^{3}$ Pazmany Peter Catholic University, Hungary

\begin{abstract}
Learning outcomes are an evaluation mechanism in the curriculum to achieve graduates competency standards. Student learning outcomes include cognitive, affective, and psychomotor aspects. The purpose of this research is to know the effect of DJP Model based module to student learning result of class XI. The research used experimental method with pretest-posttest control group design. The research population is all of the SMA Negeri 1 Geger with a total number of 192 students scattered into six classes. The sample which is taken by using simple random sampling technique resulted in two classes, namely $\mathrm{XI}$ class (experimental class using DJP Model module) which consist of 34 students and control class using teaching material in school which consist of 34 students. Data collection techniques are done through test (measuring cognitive learning outcomes) and non-tests (measuring affective and psychomotor learning outcomes). The research instruments used in this research were multiple choice questions, observation sheets, and documentation. The data were analyzed using SPSS $18 \mathrm{t}$-test with significance level of 0.05 . The result of the analysis showed the experimental cognitive learning result of experimental class is higher $(75,29$ with $76,47 \%$ completeness) than control class (59,12 with $8,82 \%$ completeness) with significance level 0,000 . The affective learning outcomes of experimental class were higher (89.78) than the control class (23.43) with significance level of 0.000 . The experimental psychomotor learning outcomes of experimental class were higher $(90.72)$ than control class $(9,84)$ with a significance level of 0.000 . Based on the results of the research can be concluded that the DJP Model-based Module gives positive effect on student learning outcomes of XI graders.
\end{abstract}

Keywords: DJP Model; learning outcome; module

Recommended citation: Suciati, S., Maridi, M., Dewi, N. K., Subandowo, D., \& Sasmito, A. (2020). Effect of Dao Jiang Ping (DJP) Model Based Module on Learning Result of XI Class Students. Journal of Innovation in Educational and Cultural Research, 1(1), 30-40

\section{INTRODUCTION}

Learning outcomes are knowledge, skills, and attitudes that must be achieved at the end of learning as a form of evaluation (Benander \& CETL, 2009; Cong, et al., 2017; Anthonysamy, 2020). Learning outcomes are used as a measurement of the teaching and learning quality (Aulia, 2013). To some countries in the world, learning outcomes are used as a reference to improve learning, teaching, and academic programs as well as student achievement evaluation (Hagerstown, 2011). In addition, learning outcomes are also important for the achievement of the goals of science, especially in learning, as science aims to find out how far the students can master the concept of learning given (Yager, 2008; Wan, 2019).

In Indonesia, the learning outcomes is meant to monitor and evaluate the process, progress, and continuous improvement of learning as how developed and developing countries are. Learning outcome is also serves as the benchmarks of elementary and secondary education completeness, where assessment refers to the affective, cognitive, and psychomotor skills (Regulation of the Minister of Education and Culture of the Republic of Indonesia No. 20 and 23 of 2016). Affective, cognitive, and psychomotor learning results obtained from the learning process in the classroom as a form of learning objectives achievement. Learning is said to be successful when the student successfully achieves the target of learning outcomes as determined (Lim, 2016).

The ground fact shows that students' learning outcomes are still quite low. It is shown by the average learning outcomes in one of the secondary schools in Malang where it reached only 52.9 (Pratiwi, et al. 2013); other research results mentioned that $63.8 \%$ of students in one of the secondary schools in Padang are still could not complete the learning target (Aulia, 2013); and also a high school in Singaraja where its value is still below the minimum mastery criteria (Jaya, 2011). The low learning outcome is caused by several factors such as the source of learning which is an important role in classroom learning (Nuryana \& Aprismayanti, 2010; Purnomo, 2012).

One learning resource which can optimize the learning outcomes is module (Purnomo, 2012). Module provides students with the opportunity to empower the learning process optimally in accordance with the level of ability and material acquired (Pratiwi, et al. 2013). Modules can encourage students participate actively in learning so that it gives impact on student learning outcomes (Shaheen \& Khatoon, 2017). Module also includes assessment 
or evaluation to measure students' learning outcomes (Nuryana \& Aprismayanti, 2010). Modules which are used in learning will have an impact on mastery of biological concepts and can be used in accordance with the learning styles of each student (Alias, et al. 2014). The module also provides an important role for students in solving problems and finding the concept of material independently so as to be able to keep in mind the concept that is owned and active in learning, creating an interactive environment, and impact on the achievement of students' learning outcomes (Dhamija, \& Kumari, 2016). In addition, the module also provides benefits in generating students' interest in learning to create an active response and improve student learning skills (Lim, 2016).

Modules will be more effective in improving learning outcomes when integrated with appropriate learning models (Firdaus, 2014). Moreover, the addition of a learning model in the module will enhance students' interest in learning (Shaheen \& Khatoon, 2017). One of the most suitable models is the Dao Jiang Ping (DJP) model. The steps in DGT model are including those activities to include all the syntax of the DJP Model namely: observation (A preview section), deep thinking section, experiment (An exercise section), problems solving, answers and explains experimental results (explaining theories), and peers evaluation (evaluation) (Wang \& Wang, 2013). With DJP Model, students will learn more meaningfully. Modules integrated with the model will be more effective in developing students' knowledge and skills (Lim, 2016).

Modules make students learn independently and are able to find their own concepts. DJP model makes students learn through the observation and investigation so that the material studied is more easily understood and remembered by students an it might give an impact on the learning outcome. The purpose of this research is to know the effect of DJP Model based module to student learning result of class XI. Learning outcomes referred to in this study of the learning process using modules.

\section{METHODS}

This research is conducted using the experimental method. The experimental method was chosen because the research was done by testing the science module to know the impact of the students' learning outcomes and compare with the students' learning result of the control class which use the teaching materials in the school. The research design used was pretest-posttest control group design, as shown by Table 1.

\begin{tabular}{cccc}
\multicolumn{4}{c}{ Table 1. Research Design } \\
\hline Class & Pretest & Treatment & Posttest \\
\hline Control & $\mathrm{A}_{1}$ & $\mathrm{X}_{1}$ & $\mathrm{~A}_{2}$ \\
Treatment & $\mathrm{A}_{3}$ & $\mathrm{X}_{2}$ & $\mathrm{~A}_{4}$
\end{tabular}

Sumber: (Sugiyono, 2013). Information: $A 1=$ Pretest in the control class; $A 2=$ Posttest on the control class; $A 3=$ Pretest in the research class; $\mathrm{A} 4=$ Posttest in the research class; $\mathrm{X} 1=$ Treatment of control class (using teaching material in school); X2 = Classroom research treatment (using DJP Model based module)

\section{Participants}

The study population is all of XI MIA class of SMA Negeri 1 Geger with 192 students spread into six classes including XI MIA 1, XI MIA 2, XI MIA 3, XI MIA 4, XI MIA 5, and XI MIA 6. The sampling technique used in this research is simple random sampling technique and obtained a sample of two classes of XI MIA 3 class (experimental class using DJP Model module) with 34 students and XI MIA 6 class (control class using teaching materials available in the school) with 34 students. The number of male participants is 12, while female participants are 22. All participants from the same school have the same habit characteristics.

\section{Instrument}

Research instruments for non-test techniques used are observation sheets developed following learning indicators and assessed by three observers to avoid subjective assessment as well as documentation methods which uses data from video, audio, and video during the learning process. The instrument used to measure learning outcomes in the form of test questions, multiple-choice types with five answer choices. Instruments for affective and psychomotor assessment of students use observational instruments in study participants. Before being used, all item test items have been declared valid and reliable from the results of the validity and reliability test.

\section{Data Collection}

The data collection technique was tested before treatment and after treatment to measure students' cognitive learning outcomes and non-test to measure students' affective and psychomotor learning outcomes. The research instrument used for the test is a matter of multiple-choice, which consist of 30 questions that have been tested to obtain valid and reliable test questions. 


\section{Data Analysis}

Data analysis techniques used under the Ministry of Education and Culture Regulation No. $81 \mathrm{~A}$ Year 2013 as Scoring Techniques of Affective and Psychomotor Learning Outcomes:

$$
\frac{\sum \text { Obtained Score }}{\sum \text { Total Score }} x 100
$$

Information:

$\mathrm{K}=$ Less Good = when obtaining score $\leq 40$

$C=$ Good Enough $=$ if score range between $41-60$

$\mathrm{B}=$ Good $\quad=$ if score range between $61-80$

$\mathrm{BS}=$ Very Good = when obtaining a score of $81-100$

Scoring Techniques of Cognitive Learning Outcomes:

$\underline{\sum \text { The Correct Answer }} \times 100$

$\sum$ Total Question

Information: Minimum Exhaustiveness Criteria or Minimum Score Value is 70.

Initial data analysis is done with the description of learning result data based on achievement, mastery, and percentage of students' mastery at each value interval. The data obtained then performed statistical analysis with SPSS assisted 18. Statistical data analysis begins with an analysis of the prerequisite test. The normality test to determine the samples uses normal or not normal distribution and homogeneity test to determine the samples on whether they have the same variation. If the data is normal and homogeneous, then the test statistic proceeds with the parametric test that is independent t-test and if the data is not normal and not homogeneous followed by the non-parametric test that is Mann-Whitney Test.

\section{RESULT AND DISCUSSION}

Based on the research that has been done, it has been obtained that the students' learning outcomes are cognitive, affective, and psychomotor. The description of the complete learning result is presented in three consecutive images namely: Figure 1 ,which is the pretest and posttest achievement of the cognitive learning outcomes of the control class, Figure 2, which is the pretest and posttest achievement of experimental class cognitive learning outcomes, and Figure 3, which is the achievement of cognitive learning outcomes, affective, and psychomotor in both the control class and the experimental class. The description of the complete data is described as follows.

\section{Student Cognitive Learning Outcome}

\section{Data Description}

Cognitive Learning Outcome of Control Class

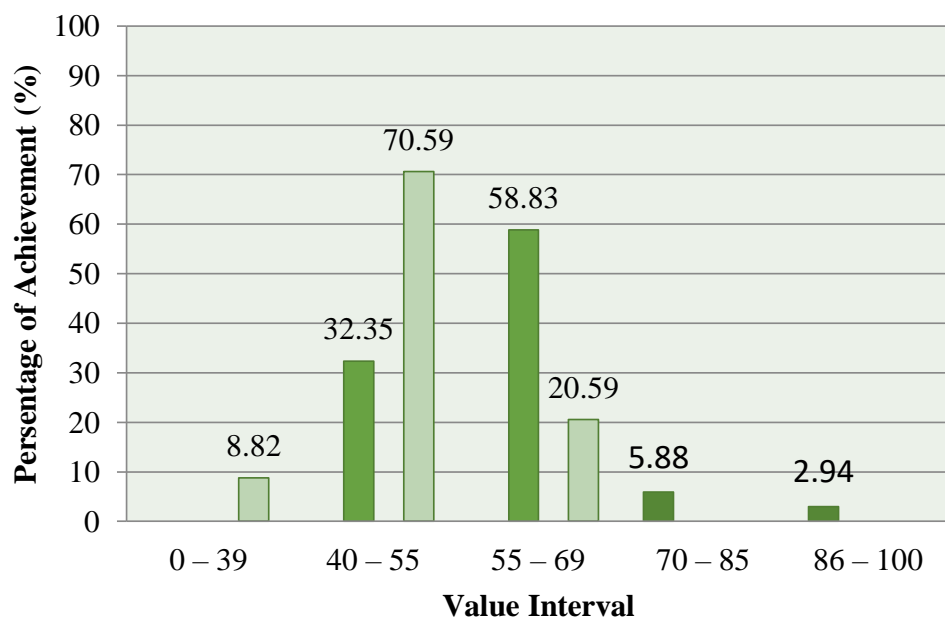

Figure 1. Cognitive Learning Outcome of Control Class
- Posttest Complete

$\square$ Posttest Incomplete

$\square$ Pretest Complete

$\square$ Pretest Incomplete 
Based on the results of cognitive learning control class in Figure 1, it can be seen that the increase in cognitive learning outcomes of control class is still low. Based on Minimum Completeness Criteria that is 70, pretest value of cognitive learning result of control class shows that no student reaching $(0 \%)$. While the percentage of students who do not complete pretest consists of: interval value 0 - 39 by $8.82 \% ; 40$ - 55 value intervals of $70.59 \%$; interval value $55-69$ by $20.59 \%$. After the study of posttest value of cognitive learning result, there are only $8.82 \%$ of the students who complete the test, consist of: interval value $70-85$ equal to $5,88 \%$ and interval value 86 - 100 equal to 2,94\%. Most students are not complete when the posttest reaches $91.18 \%$ consisting of: 40 55 value interval of $32.35 \%$; $55-69$ interval value of $58.83 \%$.

Cognitive Learning Outcome of Experiment Class

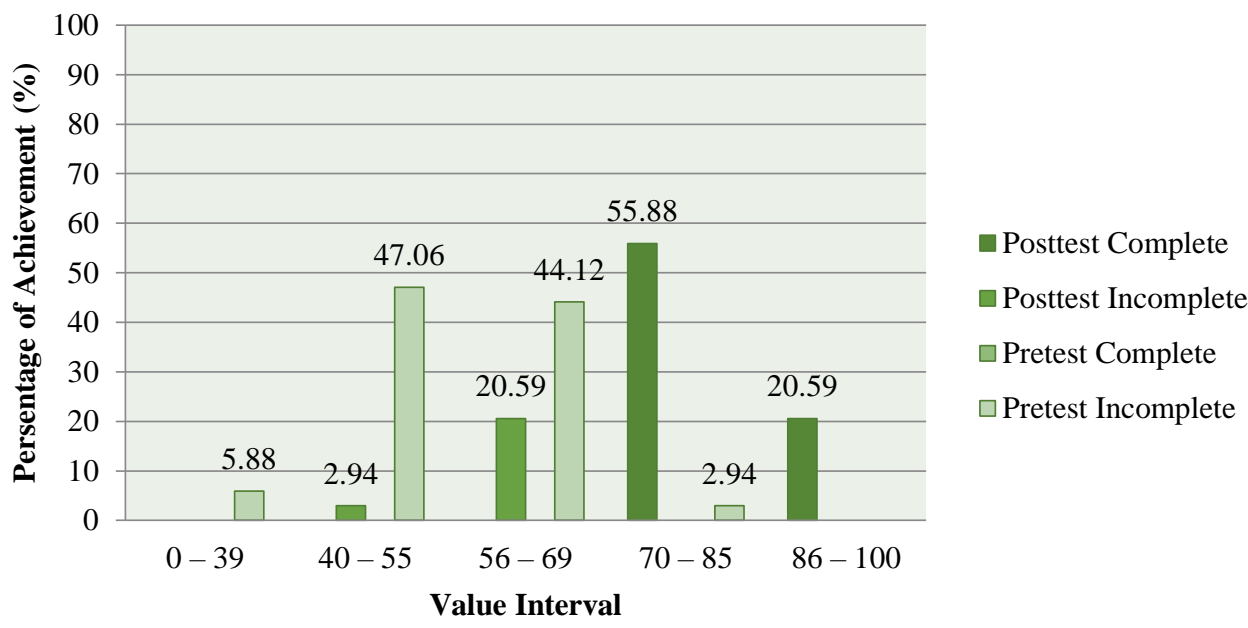

Figure 2. Cognitive Learning Outcome of Experiment Class

Based on the cognitive learning result of the experimental class students in Figure 2, it can be seen that the increase of cognitive learning outcomes of the experimental class is higher than the control class. Based on Minimum Completeness Criteria that is 70 , pretest value of cognitive learning result of experiment class shows that there is only one student reach at interval of $70-85$ equal to $2,94 \%$. While the percentage of students who do not complete pretest in the experimental class is still quite high at $91.06 \%$ consisting of: interval value $0-39$ of $5.88 \%$; 40 - 55 value interval of $47.06 \%$; 55 - 69 intervals of $44.12 \%$. After the experiment was conducted with experimental class using DJP-based science module Model, a good posttest result of cognitive learning result was obtained, from the previous only $2,94 \%$ completed students to become $76,47 \%$ completed students, consist of: interval value of $70-85$ equal to $55,88 \%$ and interval value of $86-100$ equal to $20,59 \%$. Uncompleted students' remaining posttest dropped to $23.53 \%$ consisting of: 40 - 55 value intervals of $2.94 \%$; $55-69$ interval value of $20.59 \%$. Improvement of cognitive learning outcomes of experiment class students is better than control class.

\section{Result of Statistic Test}

The statistical test results were obtained from entering the cognitive learning result data during the experimental as well as the control class pretest and posttest data. The results of statistical tests of pretest and posttest data on cognitive learning outcomes are presented in Table 2 and Table 3.

Table 2. Statistical Test of Pretest Result

\begin{tabular}{|c|c|c|c|c|}
\hline Test & Type of test & Result & Decision & Conclusion \\
\hline Normality & Kolmogorov-Smirnov & $\begin{array}{l}\text { Sig control }=0,077 \\
\text { Sig experiment }=0,200\end{array}$ & H0 accepted & \\
\hline $\begin{array}{l}\text { Homogeneity } \\
\text { Statistic data result }\end{array}$ & $\begin{array}{l}\text { Leneve-Test } \\
\text { Independent t-test }\end{array}$ & $\begin{array}{l}\text { Sig }=0,252 \\
\text { Sig }(2 \text {-tailed })=0,051\end{array}$ & $\begin{array}{l}\text { HO accepted } \\
\text { HO accepted }\end{array}$ & $\begin{array}{l}\text { The data is homogeny } \\
\text { No significant difference }\end{array}$ \\
\hline
\end{tabular}

Based on the results of statistical tests in Table 2 , can be seen that the results of normality test data obtained the significance level of control class of 0.077 and the experimental class of 0.200 . The significance value of both classes > significance $\mathrm{a}=0.05$; the decision of the hypothesis is $\mathrm{H} 0$ accepted, it is interpreted that the pretest data of both classes are normally distributed. Homogeneity test on pretest data of cognitive learning result of students obtained significance level of $0,252>a=0,05$; the decision of hypothesis is $\mathrm{HO}$ accepted, it can be inter- 
preted that the variation of the same or homogeneous data. Based on the statistical calculation, the significance is $0,051>0,05$ so that $\mathrm{HO}$ is accepted. It can be interpreted that the pretest of cognitive learning result of experiment and control class students are not significantly different.

Obtaining of posttest statistic test of cognitive learning result of experiment and control class student is done after experimental class using DGT-based Model Module and control class using teaching material in school. The results of statistical tests can be presented as in Table 3.

Table 3. Statistical Test on Cognitive Result of Posttest Cognitive

\begin{tabular}{|c|c|c|c|c|}
\hline Test & Type of test & Result & Decision & Conclusion \\
\hline Normality & $\begin{array}{l}\text { Kolmogorov- } \\
\text { Smirnov }\end{array}$ & $\begin{array}{l}\text { Sig control }=0,147 \\
\text { Sig experiment }=0,089\end{array}$ & H0 accepted & The data is normal \\
\hline $\begin{array}{l}\text { Homogeneity } \\
\text { Statistical test result }\end{array}$ & $\begin{array}{l}\text { Leneve-Test } \\
\text { Indenenden t-test }\end{array}$ & $\begin{array}{l}\text { Sig }=0,243 \\
\text { Sig (2-tailed })=0,000\end{array}$ & $\begin{array}{l}\text { HO accepted } \\
\text { HO reiected }\end{array}$ & $\begin{array}{l}\text { The data is gomogen } \\
\text { There is sianificant difference }\end{array}$ \\
\hline
\end{tabular}

The result of statistical test as shown in Table 3 shows that the normality test data of significance level of control class is 0,147 and experiment class is 0,089. The significance of the class of $>0.05$ so that $\mathrm{H} 0$ is accepted, it indicates that the posttest of the learning outcomes of the two classes is normally distributed. Homogeneity test results obtained significance level of $0.243>0.05$ so $\mathrm{HO}$ accepted, which shows homogeneous data. The statistical test is continued with parametric test in the form of Independent t-test. The statistical test results obtained a significance of $0.000<0,05$ so $\mathrm{H} 0$ rejected. It can be interpreted that the cognitive learning outcomes of the experimental class students after using the DJP-based science module model differ significantly with the control class using the teaching materials present in the school.

\section{Cognitive, Affective, and Psychomotor Learning Outcome \\ Data Description}

Achievement of affective and psychomotor learning outcomes of the students shows that there is a difference between experiment and control class. There is a significant increase of affective and psychomotor learning outcomes of experimental class students. The result of affective and psychomotor learning result of the students in the control class is still low. In general, the difference between students' affective, cognitive, and psychomotor learning outcomes can be seen as in Figure 3.

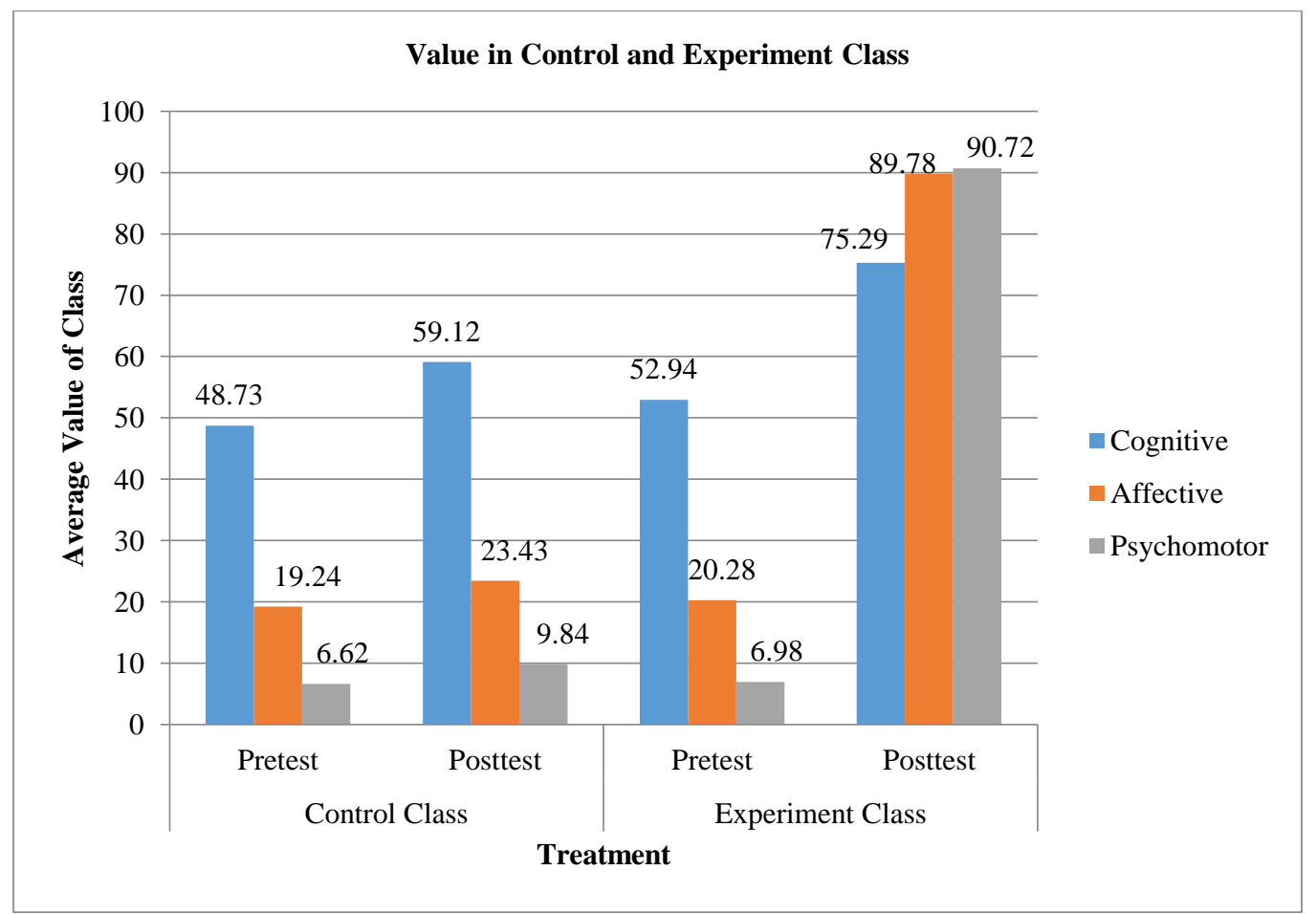

Figure 3. Student Learning Outcome Experiment Class and Control Class

Based on the value of student learning outcomes obtained during the research as in Figure 3 , it can be seen that the increase in experimental class learning outcomes is higher than the control class. The results can be seen 
from the difference in the value of student learning outcomes in pretest and posttest. The improvement of learning outcomes of control class students is still relatively low, which can be seen from the difference in learning outcomes as shown in Figure 3, namely: the difference in the increase of cognitive learning outcomes of control class by 10.39; the difference of affective learning result of 4.19; and the difference in psychomotor learning outcome of 3.22. Contrary to the control class learning outcomes, the improvement of experimental class is high and good. Based on Figure 3. can be seen the difference of cognitive learning result of experiment class which is 22,35; the difference of affective learning result is 69,5; and difference of psychomotor learning result equal to 83,74 . Based on the data obtained can be seen that the experimental class learning outcomes are better than the control class. Research data obtained to know the significance or significant difference in the increase of learning outcomes where it is necessary to do statistical tests.

\section{Result of Statistic Test}

Statistic Test Result of Student Affective Learning Outcome

The next data is the result of student affective skills. The data were obtained from the learning process. The result of statistical test of student affective skills result is presented in Table 4.

Table 4. Statistical Test of Affective Skills Pretest

\begin{tabular}{|c|c|c|c|c|}
\hline Test & Type of test & Result & Decision & Conclusion \\
\hline Normality & $\begin{array}{l}\text { Kolmogorov- } \\
\text { Smirnov }\end{array}$ & $\begin{array}{l}\text { Sig control }=0,006 \\
\text { Sig experiment }=0,042\end{array}$ & $\mathrm{H} 0$ rejected & The data is not normal \\
\hline $\begin{array}{l}\text { Homogeneity } \\
\text { Statistical test result }\end{array}$ & $\begin{array}{l}\text { Leneve-Test } \\
\text { Mann-Whitnev }\end{array}$ & $\begin{array}{l}\text { Sig }=0,183 \\
\text { Asvmn Sia }=0,086\end{array}$ & $\begin{array}{l}\mathrm{HO} \text { is accepted } \\
\mathrm{HO} \text { accepted }\end{array}$ & The data is homogenous \\
\hline
\end{tabular}

Based on pretest statistical test result of student affective learning result as shown in Table 4, it can be seen that normality test result obtained by the significance level of control class is 0,006 and experiment class is $0,042<0,05$ so that $\mathrm{HO}$ is rejected, it can be interpreted that the pretest data of affective learning result of both classes is not normally distributed. Homogeneity test obtained significance level of $0,183>0,05$ so that HO is accepted, it can be interpreted that the data is homogenous. The data are known as not normally distributed and homogeneous. The statistical test was continued with non-parametric test of Mann-Whitney test. The statistical test results obtained significance of $0.086>0.05$ so that $\mathrm{HO}$ is accepted. It can be interpreted that the pretest of affective learning result of experiment and control class students is not significantly different or not significantly different.

To obtain the data after treatment in the experimental and control classes, posttest statistical test of affective learning was conducted with the result of experiment and control class as presented as in Table 5.

Table 5. Statistical Posttest Test if Affective Skills

\begin{tabular}{|c|c|c|c|c|}
\hline Test & Type of test & Result & Decision & Conclusion \\
\hline Normality & $\begin{array}{l}\text { Kolmogorov- } \\
\text { Smirnov }\end{array}$ & $\begin{array}{l}\text { Sig control }=0,000 \\
\text { Sig experiment }=0,000\end{array}$ & $\mathrm{H} 0$ is rejected & The data is not normal \\
\hline $\begin{array}{l}\text { Homogeneity } \\
\text { The statictical result }\end{array}$ & $\begin{array}{l}\text { Leneve-Test } \\
\text { Mann-Whitney }\end{array}$ & $\begin{array}{l}\text { Sig }=0,000 \\
\text { Asymp. Siq }=0,000\end{array}$ & $\begin{array}{l}\mathrm{HO} \text { is rejected } \\
\mathrm{HO} \text { is rejected }\end{array}$ & $\begin{array}{l}\text { The data is not homogenous } \\
\text { There is significant difference }\end{array}$ \\
\hline
\end{tabular}

The result of the statistical test in Table 5 shows that the normality test of the data obtained the significance level of the control class and the experimental class of $0,000<0,05$ so that $\mathrm{H} 0$ is rejected, it shows that posttest of affective learning result of control and experiment class students is not normally distributed. Data of affective learning result of second class posttest tested homogeneity shows the result of level of significance equal to $0,000<0,05$ so $\mathrm{HO}$ is rejected which shows that the data not homogeneous. Based on the prerequisite test it can be seen that the data is not normally distributed and not homogeneous. The statistical test was continued with a non-parametric Mann-Whitney test. Based on the statistical test, the significance of $0.000<0,05$ and the hypothesis decision is $\mathrm{HO}$ rejected. Non parametric test results can be interpreted that the affective learning result of the experimental class students after using DJP-based science module Model is significantly different with the control class using the teaching materials available in the school.

\section{Statistic Test Result of Student Psychomotor Learning Outcome}

The next learning result is the result of student affective learning. Data obtained from the learning process. The result of statistical test of student psychomotor learning result can seen from in Table 6. 
Table 6. The Result of Statistical Pretest of Psychomotor Learning

\begin{tabular}{|c|c|c|c|c|}
\hline Test & Type of test & Result & Decision & Conclusion \\
\hline Normality & $\begin{array}{l}\text { Kolmogorov- } \\
\text { Smirnov }\end{array}$ & $\begin{array}{l}\text { Sig control }=0,038 \\
\text { Sig experiment }=0,012\end{array}$ & $\mathrm{HO}$ is rejected & The data is not normal \\
\hline $\begin{array}{l}\text { Homogeneity } \\
\text { Statistical test result }\end{array}$ & $\begin{array}{l}\text { Leneve-Test } \\
\text { Mann-Whitney }\end{array}$ & $\begin{array}{l}\text { Sig }=0,045 \\
\text { Asymp. Sig }=0,157\end{array}$ & $\begin{array}{l}\mathrm{HO} \text { is rejected } \\
\mathrm{HO} \text { is accepted }\end{array}$ & $\begin{array}{l}\text { The data is not homogenous } \\
\text { There is no significant difference }\end{array}$ \\
\hline
\end{tabular}

The test results obtained as in Table 6 shows that the normality test of the data reached the level of significance of control class of 0.038 while 0.012 were obtained by the experimental class. The significance value of the two classes $<0.05$ so that $\mathrm{H} 0$ is rejected, it can be interpreted the pretest data of the experimental and control class is not normally distributed. Homogeneity test obtained the level of significance $0,045<0,05$ so that $\mathrm{HO}$ is rejected, it can be interpreted that there is variation of non-homogeneous data. Pretest data of psychomotor learning outcomes of control and experiment class students are known to be not normally distributed and not homogeneous. The statistical test was continued with a non-parametric Mann-Whitney test. The result of statistical test reached the significance value equal to $0,157>$ significant level of 0,05 ; the decision of hypothesis is $\mathrm{H} 0$ is accepted. It can be interpreted that the pretest of psychomotor learning result of experiment and control class students are not significantly different.

The next step of the research is treating the experimental class with learning using DJP-Based model of science module while the control class were taught by using teaching materials in school. Psychomotor assessment is done during the implementation of learning. Obtaining data of psychomotor learning result of experiment class and control class then conducted by posttest statistic test which result presented as pads in Table 7.

Table 7. Statistical Posttest Test of Psychomotor Result

\begin{tabular}{|c|c|c|c|c|}
\hline Test & Type of test & Result & Decision & Conclusion \\
\hline Normality & $\begin{array}{l}\text { Kolmogorov- } \\
\text { Smirnov }\end{array}$ & $\begin{array}{l}\text { Sig control }=0,000 \\
\text { Sig experiment }=0,000\end{array}$ & $\mathrm{HO}$ is rejected & The data is not normal \\
\hline $\begin{array}{l}\text { Homogeneity } \\
\text { Statistical test result }\end{array}$ & $\begin{array}{l}\text { Leneve-Test } \\
\text { Mann-Whitney }\end{array}$ & $\begin{array}{l}\text { Sig }=0,000 \\
\text { Asymp. Sig }=0,000\end{array}$ & $\begin{array}{l}\mathrm{HO} \text { is rejected } \\
\mathrm{HO} \text { is rejected }\end{array}$ & $\begin{array}{l}\text { The data is not homogenous } \\
\text { There is significant difference }\end{array}$ \\
\hline
\end{tabular}

The result of statistical posttest test as shown in Table 7 shows that the prerequisite test is the result of normality test of the data obtained the level of significance of the control class and the experimental class of 0.000 . Significance of both classes $>0.05$; HO hypothesis decision is rejected, it shows that the data of both classes are not normally distributed. Posttest data of psychomotor learning result of both classes were tested homogeneity got result of significance level equal to 0.000 , result significance $<0,05$ so $\mathrm{H} 0$ rejected, this shows that the students' data of second class is not homogeneous. Based on the prerequisite test known data is not normally distributed and not homogeneous. The statistical test was continued with the Mann-Whitney test. Based on non parametric statistical test conducted, it was obtained the significance of $0.000<0,05$ and the decision of hypothesis is $\mathrm{HO}$ rejected. This shows the results of psychomotor learning of experimental class students after using DJPbased science module Model significantly different or significant with the control class using the teaching materials available in the school.

Based on Figure 3, it can be seen that the difference in affective class learning outcomes of experiment and control groups is very high where it reached 66.35 at the posttest, the difference rises considerably because at the time of pretest, it was only discorded 3.15 and the value of more control classes. This can happen because the learning activities conducted by the students based on the activity in the module of science where it contains syntaxes of the DJP Model which gives impact on the attitude of students in learning that is able to empower and shape the character of students. This is similar to the research conducted (Alias \& Siraj, 2012; Li, et al. 2020).) which states that the modules are compiled and integrated with the model of learning to give effective impact and influence on learning styles and become appropriate to technology. Good affective learning results will form a good character as well. Other results also suggest that the learning model-based Module also has an impact on the affective sphere where it is able to facilitate in shaping the student's character (Hardoko, et al., 2014). This opinion is reinforced by the results of other research which states that by utilizing the module in learning will gain a higher positive attitude and characterize students after the completion of learning (Nyabiosi, et al. 2017). Not only able to form the character of the students, the significance of the DJP Model-based module to the learning outcomes is also due to the effect of changing attitudes of students interested in the module. The result of the research mentioned that the attitude of the students who are happy and interested in the module is a good asset before the students learn the contents in the module so that it impacts the students' learning outcomes (Purnomo, 2012; Hatton, et al. (2020)). 
In addition to the high affective learning outcomes after using the module, cognitive learning outcomes also increased after its use. Based on Figure 3, it can be seen that the average of cognitive learning outcomes of students is higher than the average of cognitive learning outcomes in the control class, this is indicated by the average of experimental class cognitive learning outcomes of 75.29 and control classes 59.12 . The high value of cognitive and affective learning outcomes of students in accordance with the research (Abualrob \& Shah, 2012) which states that the utilization of modules in learning to improve student learning value and attitude changes in implementing learning. The results of other studies also mention that the improvement of students' cognitive learning outcomes will also be followed by the increased of student affective learning outcomes (Alias, et al. 2014).

Based on the results of experimental study, experimental class obtained higher cognitive result than the control class as presented in Figure 2. The high percentage of mastery of cognitive learning outcomes of experimental class students cannot be separated from the role of the module, DJP-based model module makes students remember the material longer and more meaningful. This is supported by the results of research that says that the advantages of learning by using modules such as students learn independently and accelerate students in mastery of learning materials (Nuryana \& Aprismayanti, 2010). The results obtained shows that DJP-based science module model has a positive impact when it is used in learning. The results obtained similar to other studies also mention that students' learning outcomes also become more satisfactory when the module designed is implemented in learning (Dumitrescu, et al. 2014). This is reinforced by the results of research which mentions that the module can play a significant role in improving students' cognitive learning outcomes in the classroom (Lee \& Osman, 2011; Vyas \& Vashishtha, 2013). Other results suggest that learning using modules will have a significant impact on student learning outcomes, as indicated by the increase in students' test scores (Alias, et al. 2014). In line with the research mentioned that the module is effective in improving student learning outcomes (Alias \& Siraj, 2012).

Utilization of the module in learning also affects the students' learning completeness where $76.47 \%$ of the experimental class students get the value of $\geq$ Minimum completeness criteria which is 70 . The results obtained in accordance with the results of other studies that said students who use the module in learning to get a minimum cognitive value from $85 \%$ (Tang, et al. 2015). Other research results also show that after using the module in learning, as many as $81 \%$ of 39 students better understand the concept of learning (Halim, et al. 2011). This shows that the module influences the learning process and affects the students' learning outcomes. The results of other studies mentioned that the increase in student learning outcomes because students are motivated to learn when using modules that encourage student learning outcomes (Febriana, et al. 2015). This is supported by the results of research which states that the module is able to motivate students to learn and obtain good learning outcomes because students are able to learn the module according to their own way (Lim, 2016). The application of the module in the learning will help the development of the concept owned by the students so that it adapts to the characteristics of each student and affects the optimum student learning outcomes (Sadiq \& Zamir, 2014). Other results also suggest that learning by using module materials has a positive impact on students' learning outcomes as they increase significantly (Khabibah, et al., 2017; Setyawan, et al., 2017).

Students' learning outcomes are not only the affective and cognitive aspects that are increasing, the psychomotor aspect also increases significantly. Figure 3 shows that the difference in mean learning outcomes of experimental class psychomotor during pretest and posttest is 83,74 ; while the control class difference is only 3.22 . The difference between psychomotor learning result of the experimental and control class students is caused by the experimental class students being actively involved and experiencing the learning process in the form of lab or experiment to find the material concept, while the control class get the material from the teaching materials in school which is explained between the groups through the presentation. The results of research conducted in line with other research which states that independent activities with labs can improve students psychomotor ability because their skills will be sharpened through the activity. Other research states that modules in education are useful for creating active students in the classroom through science learning activities including exploration and investigation activities and stimulating students to provide feedback after utilizing modules in science learning in the classroom. Practical activities undertaken are a learning strategy to form a direct learning experience in education (Ali et al, 2010; Padmapriya, 2015; Bouilheres, et al., 2020).

\section{CONCLUSION}

Based on the results of research can be concluded that the DJP-based module Model gives positive effect on student learning outcomes class. The experimental psychomotor learning outcomes of experimental class were higher $(90.72)$ than control class $(9,84)$ with a significance level of 0.000 . Our thanks to all teachers for their cooperation and assistance in completing the research and all parties involved in the implementation and completion of the research. 


\section{REFERENCES}

Abualrob, M. M., \& Shah, M. (2012). Science technology and society modules development process and testing on its effectiveness. Procedia - Social and Behavioral Sciences, 46 , 811-816.

Ali, R., Ghazi, S. R., Khan, M. S., Hussain, S., \& Faitma, Z. T. (2010). Effectiveness of Modular Teaching in Biology at Secondary Level. Asian Social Science, 6(9), 49-54.

Alias, N., \& Siraj, S. (2012). Effectiveness of Isman Instructional Design Model in Developing Physics Module based on Learning Style and Appropriate Technology. International Educational Technology Conference (IETC) (pp. 12-17). Elsevier Ltd.

Alias, N., DeWitt, D., Rahman, M. N., Gelamdin, R. B., Rauf, R. A., \& Siraj, S. (2014). Effectiveness of the Biology PTechLS Module in a Felda Science Centre. Malaysian Online Journal of Education Technology, 2(4), 31-36.

Anthonysamy, L., Koo, A. C., \& Hew, S. H. (2020). Self-regulated learning strategies and non-academic outcomes in higher education blended learning environments: A one decade review. Education and Information Technologies, 1-28.

Aulia, F. (2014). Pengaruh Penggunaan Modul pada Model Pembelajaran Kooperatif Tipe Student Team Achievement Divisions terhadap Hasil Belajar Siswa pada Mata Pelajaran Keterampilan Konputer dan Pengelolaan Informasi di SMK Negeri 2 Bukittinggi. Bukittinggi: Universitas Negeri Padang.

Benander, R., \& CETL. (2009). Course-Based Student Learning Outcomes Modules. Cincinnati: University of Cincinnati.

Bouilheres, F., McDonald, S., Nkhoma, C., \& Jandug-Montera, L. (2020). Defining student learning experience through blended learning. Education and Information Technologies, 1-21.

Cong, L., Yan, Q., Sun, C., Zhu, Y., \& Tu, G. (2017). Effect of problem and scripting-based learning on spine surgical trainees' learning outcomes. European Spine Journal, 26(12), 3068-3074.

Dhamija, N., \& Kumari, M. (2016). Effectiveness of Computer-Assisted Instruction on the Academic Achievement in Mathematics for Secondary School Students. International Journal of Engineering Science and Computing, 6(9), 2127-2131.

Dumitrescu, C., Oltenau, R. L., Gorghiu, L. M., \& Gorghiu, G. (2014). Learning Chemistry in the Frame of Integrated Science Modules - Romanian Students' Perception. Procedia - Social and Behavioral Sciences 116, 2516-2520.

Febriana, B. W., Ashadi, \& Masykuri, M. (2015). Effectiveness of Module Based Problem Based Learning (PBL) Toward Student's Achievement Motivation. The 1st International Seminar on Chemical Education, (pp. 30 - 38). Surakarta.

Firdaus, I., Corebima, A. D., \& Rahayu, S. E. (2015). Pengaruh Penggunaan Modul Pembelajaran Biologi berbasis Inkuiri terhadap Hasil Belajar dan Retensi Siswa Kelas X SMAN Kota Pasuruan. Malang: Universitas Negeri Malang.

Hagerstown, C. C. (2011). Student Learning Outcomes Assesment Report. Hagerstown: Hagerstown Community College.

Halim, A., Meerah, S. T., \& Halim, L. (2011). Pengembangan Modul Pembelajaran Mandiri berbasiskan Perubahan Konseptual Radikal. Jurnal Pendidikan dan Pembelajaran, 18(2), 127-132.

Hardoko, A., Salindeho, D., \& Wedi, A. (2014). Pengembangan Bahan Ajar PKn berbasis Karakter dengan Menggunakan Model Pendidikan Moral pada Siswa SMP di Kota Samarinda. Jurnal Pendidikan dan Pembelajaran, 21(1), 92-99. 
Hatton-Bowers, H., Smith, M. H., Huynh, T., Bash, K., Durden, T., Anthony, C., ... \& Lodl, K. (2020). “I Will Be Less Judgmental, More Kind, More Aware, and Resilient!”: Early Childhood Professionals' Learnings from an Online Mindfulness Module. Early Childhood Education Journal, 48(3), 379-391.

Jaya, S. P. (2011). Pengembangan Modul Fisika Kontekstual untuk Meningkatkan Hasil Belajar Fisika Peserta Didik Kelas X Semeseter 2 di SMK Negeri 3 Singaraja. Denpasar: Universitas Pendidikan Ganesha.

Kemendikbud. (2016, Juny 6). Peraturan Menteri Pendidikan dan Kebudayaan Republik Indonesia Nomor 20 Tahun 2016. Jakarta: Kementerian dan Kebudayaan Republik Indonesia.

Kemendikbud. (2016). Peraturan Menteri Pendidikan dan Kebudayaan Republik Indonesia Nomor 23 Tahun 2016. Jakarta, DKI Jakarta, Indonesia: Kementrian Pendidikan dan Kebudayaan Republik Indonesia.

Khabibah, E. N., Masykuri, M., \& Maridi. (2017). The Effectiveness of Module based on Discovery Learning to Increase Generic Science Skills. Journal of Education and Learning, 11(2), 146-153.

Lee, T. T., \& Osman, K. (2011). Effectiveness of Interactive Multimedia Module with Pedagogical Agent (IMMPA) in the Learning of Electrochemistry: A Preliminary Investigation. Asia-Pacific Forum on Science Learning and Teaching, 12(2), 1-24.

Lim, E. J. (2016). Effectiveness of Modular Instruction in Word Problem Solving of BEED Students. IOSR Journal of Mathematics, 12(5), 59-65.

Li, L., Qin, S., Lu, Z., Xu, K., \& Hu, Z. (2020). One-shot learning gesture recognition based on joint training of 3D ResNet and memory module. Multimed Tools Appl, 79(9), 6727-6757.

Nuryana, \& Aprismayanti, E. (2010). Pengaruh Penggunaan Modul terhadap Hasil Belajar Siswa pada Mata Pelajaran Matematika Kelas VII SMP Negeri 8 Kota Cirebon. Cirebon: IAIN Syekh Nurjati Cirebon.

Nyabiosi, H., Wachanga, S. W., \& Buliba, A. (2017). Relative Effects of Cooperative Learning Approach on Secondary School Students' Attitudes in Kiswahili Language Comprehension in Kisii Central Sub-Country, Kenya. International Journal of Humanities Social Sciences and Education, 4(3), 95-106.

Padmapriya, P. V. (2015). Effectiveness of Self Learning Modules on Achievement in Biology Among Secondary School Students. International Journal of Education and Psycological Research, 4(2), 44-46.

Pratiwi, H. E., Suwono, H., \& Handayani, N. (2014). Pengembangan Modul Pembelajaran Biologi berbasis Hybrid Learning untuk Meningkatkan Kemampuan Berpikir Kritis dan Hasil Belajar Siswa Kelas XI. Malang: Universitas Negeri Malang.

Purnomo, D. (2012). Pengaruh Penggunaan Modul Hasil Penelitian Pencemaran di Sungai Pepe Surakarta sebagai Sumber Belajar Biologi Pokok Bahasan Pencemaran Lingkungan terhadap Hasil Belajar Siswa. Surakarta: Universitas Sebelas Maret.

Sadiq, S., \& Zamir, S. (2014). Effectiveness of Modular Approach in Teaching at University Level. Journal of Education and Practice, 5(17), 103-109.

Setyawan, D. N., Aminah, N. S., \& Sarwanto. (2017). The Using of Scientific based Physics Module in Learning to Enhance High School Students' Cricital Thinking Skills on Rotation Dynamics and Equilibrium of Rigid Body. Journal of Education and Learning, 11(2), 213-218.

Shaheen, S., \& Khatoon, S. (2017). Impact of ICT Enriched Modular Approach on Academic Achievement of Biology Students. Journal of Research and Reflections in Education. 11(1), 49-59.

Sugiyono. (2013). Metode Penelitian Pendidikan (Pendekatan Kuantitatif, Kualitatif, dan R\&D). Bandung: CV. Alfabeta.

Tang, M. R., Jufri, \& Sultan. (2015). Pengembangan Bahan Ajar Cerita Fiksi berbasis Wacana Budaya di Sekolah Dasar. Jurnal Pendidikan dan Pembelajaran, 22(2), 169-175. 
Vyas, K., \& Vashishtha, K. C. (2013). Effectiveness of Teaching based on Brain Research with Reference to Academic Achievement of Secondary School Students. International Journal of Students Research in Technology \& Management, 1(4), 383-397.

Wang, F., \& Wang, X. (2013). How Students Learn Knowledge from Classroom Interaction. Mathematics Education in China, $11,3-6$.

Wan, Z. H. (2019). Exploring the Effects of Intrinsic Motive, Utilitarian Motive, and Self-Efficacy on Students' Science Learning in the Classroom Using the Expectancy-Value Theory. Research in Science Education, 113.

Yager, R. E. (2008). Comparison of Student Learning Outcomes in Middle School Science Classes with an STS Approach and a Typical Textbook Dominated Approach. Research in Middle Level Education, 31(7) , 1-16. 